\title{
The Case for the Recognition of Krav-Maga as Part of the Intangible Cultural Heritage of Israel
}

\author{
Guy Mor \\ School of Martial Arts, Shanghai University of Sport, Shanghai, China \\ Email: drguymor@gmail.com
}

How to cite this paper: Mor, G. (2019) The Case for the Recognition of Krav-Maga as Part of the Intangible Cultural Heritage of Israel. Open Journal of Social Sciences, 7 , 294-303.

https://doi.org/10.4236/jss.2019.74023

Received: March 20, 2019

Accepted: April 20, 2019

Published: April 23, 2019

Copyright ( 2019 by author(s) and Scientific Research Publishing Inc. This work is licensed under the Creative Commons Attribution International License (CC BY 4.0).

http://creativecommons.org/licenses/by/4.0/

\section{cc) (i) Open Access}

\begin{abstract}
Krav-Maga ("contact combat") has attracted increasing attention, both in Israel and abroad, as a civilian combat discipline, a martial art and an effective self-defense system used by the Israel Defense Forces (IDF). This paper explores the interactions between the development of Krav-Maga and the history, culture and heritage of the Jewish population of Israel. Using qualitative research methods, it is demonstrated that the evolution of Krav-Maga is intertwined with ideological changes and historical events that affected the Jewish people in the late $19^{\text {th }}$ and early $20^{\text {th }}$ centuries, and with the cultural history and identity of Jewish immigrants to Israel in the mid $20^{\text {th }}$ century. We argue that Krav-Maga meets the criteria set out in UNESCO's definition of intangible cultural heritage and that it should be included in the Representative List of the Intangible Cultural Heritage of Israel.
\end{abstract}

\section{Keywords}

Krav-Maga, Society and Culture, Intangible Cultural Heritage, Culture History, Kapap

\section{Introduction}

Krav-Maga, meaning "contact combat", is a hand-to-hand combat discipline that was developed in the $19^{\text {th }}$ century by Jewish immigrants to (what was then) Palestine [1]. The discipline is globally associated with modern day Israel, as reflected in the media and in privately published books [2]. In recent years, Krav-Maga has been growing in popularity [3], a trend which may be attributed to the global increase in terrorist actions against civilians, such as the Charlie Hebdo shooting in 2015 [4], and to the reputation of Krav-Maga as the official hand-to-hand combat method of the Israeli Defense Forces (IDF) [5]. Despite this growth in popularity, little scholarly research has been undertaken to ex- 
amine the historical origins and evolution of Krav-Maga, nor how these are linked to the cultural heritage of the Jewish people. Both of these intellectual projects are important if the case including Krav-Maga within the ambit of the intangible cultural heritage of Israel is to be evaluated. It is worth noting that some recent work has been carried out [6] on the link between the emergence of Krav-Maga and the violent relations between Jewish and Arab residents of Palestine in the late $19^{\text {th }}$ century [7]. However, this work does not examine the cultural and ideological dimensions of the development of Krav-Maga.

In the current study, we examine the evolution of Krav-Maga in more detail and seek to locate its development within the cultural and ideological trends that fashioned the development of Jewish consciousness during the late $19^{\text {th }}$ century and the first half of the $20^{\text {th }}$ century. We argue that these socio-cultural trends found their natural expression in the establishment of the State of Israel and that Krav-Maga therefore qualifies as part of the intangible cultural heritage of the Israeli nation.

\section{The Meaning of Intangible Cultural Heritage (ICH)}

To establish the argument that Krav-Maga should be considered as part of Israel's intangible cultural heritage (ICH), it is necessary to define what the term means. In the scholarly literature, "heritage" is generally treated as a concept that reflects the way in which a group understands its history processed through time [8]. There are numerous, more subtle ways of construing the notions of culture and heritage [9]. However, for the present purposes, it is sufficient to rely on UNESCO's (2003) definition of ICH:

"intangible cultural heritage" means the practices, representations, expressions, knowledge, skills - as well as the instruments, objects, artifacts and cultural spaces associated therewith-that communities, groups and, in some cases, individuals recognize as part of their cultural heritage. This intangible cultural heritage, transmitted from generation to generation, is constantly recreated by communities and groups in response to their environment, their interaction with nature and their history, and provides them with a sense of identity and continuity, thus promoting respect for cultural diversity and human creativity" [10].

This definition provides an understanding of the elements that are required for something to fall within the category of intangible cultural heritage. The definition emphasizes the transmission and evolution of ICH through time and therefore implies that processes, knowledge, practices (and so on) that are rooted in a people's history, and that are subject to generational change, qualify as cultural heritage. Moreover, this definition incorporates the idea that the processes that make up the ICH must function subjectively as part of a nation's identity or heritage.

In this paper we seek to demonstrate that Krav-Maga is a body of knowledge, a practice and a skill that is transmitted from generation to generation. We will 
show that its form evolves through time, and that its evolution interacts with the history, culture and heritage of the Israeli people. Further, it will be shown that Krav-Maga underpins a sense of Israeli national identity, but also promotes cooperation between individuals with different national identities. For these reasons, it is argued that it constitutes part of the intangible cultural heritage of Israel.

\section{Historic Events Leading to the Creation of a New Ideology and Culture (1782-1903)}

For many years, Jews, as a minority, were subjected to systematic persecution, such as their enforced exile from Prague in 1744 and their exposure to the Damascus blood libel in 1840 [11]. However, hope for a safer and better life began to spread in the late $18^{\text {th }}$ century when Emperor Joseph II of the Habsburg Monarchy granted religious freedom to the Jewish population as part of his 1782 Edict of Tolerance [12]. This trend continued into the second half of the $19^{\text {th }}$ century and, in 1861, Alexander the $2^{\text {nd }}$ (Emperor of Russia) granted Jews the right to attend regular educational programs and to participate more freely in economic life-activities from which they had previously been barred [13].

However, despite these trends, anti-Semitism did not disappear and, in fact, it re-surfaced with some intensity in the Russian empire in the late $19^{\text {th }}$ century immediately following the assassination of Alexander the $2^{\text {nd }}$ in 1881 [14]. Violent attacks against Jews, known as pogroms, continued to erupt from time to time, creating a conviction among Jews that anti-Semitism in Europe was unlikely to fade. As a consequence, Jews abandoned hope of a normal life in exile and started to embrace two major new conceptions of their future-one practical and one ideological. The practical change was an increase in Jewish emigration from Russia to other countries, including but not limited to Palestine (later to become Israel). The second development was the rise of a new ideology promulgated by the Jewish leadership, one which called upon Jews to act proactively to determine their own future rather than accepting the status quo as inevitable [15].

To understand the dynamics of this ideological shift, it is necessary to examine the writings of Jewish leaders and activists who operated in this period. One such leader, Judah Leib Pinsker, in his famous article "Auto-Emancipation" (1882), called on the Jewish people to seek independence rather than relying on other nations to protect them [16]. His article opened with an ancient Hebrew saying: "If I am not for myself, who will be for me?... And if not now, when?" [17]. By associating the new ideology with this traditional aphorism, Pinsker harnessed the people's bond with their Jewish heritage, providing a powerful rationale and motivation to support the proposed ideological change.

This paradigm shift from persecuted minority to putative nation was reinforced by ongoing expressions of anti-Semitism, leading to the creation of the Zionist movement towards the end of the $19^{\text {th }}$ century [18]. This in turn triggered a series of political developments that eventually led to the establishment 
of the State of Israel in 1948. Other key Zionist leaders who sought to awaken the notion of Jews as a strong people with the capacity to defend themselves were Max Nordau and Ze'ev Jabotinsky. In 1898, Nordau coined the term "Muscular Judaism" to refer to the concept of Jews with intense national pride, physical prowess, and the ability to fight and protect themselves and their nation. Further, he linked this concept to traditional heroes such as Samson, Shimon bar Kokhba and Judas Maccabeus [19]. Echoing Pinsker's strategy, Nordau used these cultural icons to link the new ideology to ancient Jewish themes. Similarly, Ze'ev Jabotinsky founded the Jewish Self-Defense Organization in Odessa [20], and argued that athletic training should be practiced on a regular basis to ensure that the Jewish population was able to fight for its freedom and national homeland [21]. This political ideology encouraged many Jews to take a stand and immigrate to what was then Palestine - a territory governed by the Ottoman Empire [22].

\section{First Signs of a Jewish Pioneering Ethos: 1904-1914}

From 1904-1914, as the ideas of the Zionist movement spread and as anti-Semitism in Europe continued unabated, about 35,000 Jews immigrated to Palestine [23]. Most of these immigrants were young people who gave effect to the new ideology of the proud strong Jew by 1) creating a new form of agricultural settlement known as the Kibbutz, and 2) assuming responsibility for the guarding of Jewish settlements. In 1907 several new immigrants who formerly belonged to Jewish self-defense groups in Europe formed the Bar-Giyora organization. This group was named after Shimon Bar-Giyora, one of the leaders of the Jewish rebellion against the Roman occupation of Jewish land in 66 - 73 AC [24]. The name of the movement demonstrates again the practice of imbuing a contemporary emphasis on assertive self-reliance using folk memories derived from Jewish tradition. In 1908 an organization known as Hashomer ("The Guard") replaced Bar-Giyora as the movement that embodied the ethos of proud Jewish warriors and was ready to protect Jewish settlements in Palestine [25].

\section{Realization of the New Ideology during the British Mandate (1917-1948)}

In 1917 the British wrested the area of Palestine from the Ottoman Empire, creating an opportunity for the Zionist movement to promote its objectives. A key development was the "Balfour Declaration" of November $2^{\text {nd }} 1917$, which stated that the British government favored the establishment of a national homeland for the Jews in Palestine [26]. This statement led to increased Jewish immigration to Palestine [27] but also to an increase in hostile resistance by the indigenous Arab population. In response, Jewish organizations initiated forms of combat training relying mainly on known martial disciplines, such as Ju-Jitsu and boxing, combined with some practical experience and knowledge acquired by Jewish immigrants during training in their countries of origin [28]. Unfortu- 
nately, these techniques failed to save lives in real combat situations [29].

In 1920, following another wave of Arab attacks against Jewish residents, the Hagana (a Jewish paramilitary organization) was established based on the infrastructure of Hashomer [30]. The Hagana sought to develop an unarmed combat discipline that would provide effective defense against Arab attacks, and looked to experts such as Dr. Moshe Feldenkrais and others to provide advice on unarmed combat.

Feldenkrais (1904-1984), who had experience of Ju-Jitsu and other hand-to-hand combat systems, sought to create a practical and more effective solution based on his own research and incorporating the principle of "unconscious reaction" (also known as "reflexive reaction"). This approach is predicated on the assumptions that human beings have a pre-programmed system of reactions to menaces and that these reactions are performed unconsciously [31]. This insight led Feldenkrais to establish an improved fighting and training regimen whose fundamental principles were later adopted by both Kapap (an abbreviation of Krav Panim el Panim meaning "face-to-face combat") and Krav-Maga. The Hagana command considered his ideas sufficiently promising to justify the award of a three-year grant allowing Feldenkrais to train Hagana members [32].

Between 1936 and 1939, the Arab leadership felt intimidated by the expansion of Jewish numbers and recognized that they might lose their numerical advantage. Encouraged by Arab political achievements in Iraq, Egypt and Syria, the Arab revolt in Palestine was initiated with the intention of ending Jewish immigration and advancing Arab independence; it resulted in numerous casualties on all sides [33]. In the course of this violence, Jewish groups felt compelled to develop and disseminate knowledge of hand-to-hand combat techniques, alongside physical and basic military education [34]. Being under the British mandate, open training in combat disciplines was restricted, so Jewish immigrants adapted known hand-to-hand combat tactics to create a unique combat discipline, which could be represented as a "defensive sport" (Sport Magen). This discipline, which incorporated techniques from Ju-Jitsu, boxing and wrestling, as well as some of Feldenkrais's ideas, was promoted first by Gersho Kofler as a sport under the sports organization Hapoel [35]. During the same period, a British intelligence officer (Charles Orde Wingate) stationed in Palestine decided to support the Zionist cause by forming small, armed assault units of British-led Jewish commandos to counter hostile Arab actions [36]. This was a transformative moment in the development of the Zionist movement's approach, shifting from a focus on defense to the creation of a dynamic and highly effective counter-terrorism operation [37]. A further contribution to the development of the Jewish combat doctrine arose from Jewish demonstrations in protest at what were seen as discriminatory regulations proposed by the British Secretary of State for the Colonies in 1939. During these protests, British policemen used batons to beat Jewish demonstrators, causing significant demoralization within the Jewish community and the dissolution of several youth platoons [38]. This, in turn, encouraged Hagana members to conduct "combat experiments" to find a 
practical means of countering the threat of the British batons. The outcome was the introduction of a short-stick fighting method, which became an integral part of the general face-to-face combat training regimen of the time [39]. The conceptual transformation from a defensive to an offensive approach, along with the introduction of the short-stick weapon, was associated with a change in the labeling of the combat system; what was previously known as Sport Magen became Kapap [40].

The development of a local combat discipline, and the shift from defensive to active counter operations, can be seen in a broader context as part of an emerging combat culture based on proactivity, Muscular Judaism and self-reliance.

\section{The Establishment and Development of Krav-Maga in Israel (1948-1971)}

For the first decade following the declaration of Israeli independence in 1948 and the establishment of the IDF, the army's hand-to-hand combat training relied heavily on Kapap, and used instructors and training materials from the Hagana [41]. It is true that from 1948 until the late 1950s, several different terms appeared in IDF documents, but these were used interchangeably. Thus Kapap, Sport Magen and Krav-Maga [42] were all seen as variants of a common hand-to hand system. Eventually, towards the end of the period, the term Krav-Maga became the accepted term for the IDF's hand-to-hand-combat method, displacing the term Kapap altogether [43].

The most recent phase in the evolution of Krav-Maga was the development of a non-military form, often credited to Imi Lichtenfeld, a prominent hand-to-hand combat instructor and Kapap and Krav-Maga specialist within the Hagana and IDF [44]. From around 1964, Lichtenfeld was active in promoting Krav-Maga as a civilian discipline, introducing new techniques and adopting the judo belt system. In August 1971, the first civilian Krav-Maga instructor's course was held in Lichtenfeld's training club in Netanya [45].

\section{Krav-Maga Today}

Krav-Maga today is taught and practiced in three different modes: As a self-defense system, as a combat system for security forces, and as a martial art. The "unconscious reaction" principle established by Feldenkrais continues to serve as the common feature of all three manifestations of Krav-Maga. However, the particular techniques included within the Krav-Maga portfolio continue to evolve in response to changing threats, such as attempts to kidnap Israeli soldiers or snatch their rifles [46]. Thus military Krav-Maga continues as an evolving system of hand-to-hand combat.

From a civilian perspective, there are dozens of Krav-Maga organizations all over the world, each promoting participation in the discipline through courses, training camps and international events [47]. Several Israeli colleges offer Krav-Maga training programs for overseas students who may learn the discip- 
line in Israel or in external facilities located abroad [48]. Over the last two decades, a new segment of the tourism industry has emerged in Israel specifically to satisfy the demand for Krav-Maga training, sometimes paired with touring the country [49]. These training courses and "Tour and Train" experiences bring people of different nationalities together with a common interest in Krav-Maga, through which they develop a sense of identity and solidarity, create friendship bonds, and learn to respect cultural diversity.

\section{Discussion}

The argument we wish to advance is that the development of Krav-Maga is interwoven with the history and traditions of the Jewish people. The roots of this system of combat are to be found in the Jewish cultural and ideological revolution that took place in the late $19^{\text {th }}$ century. This "muscular" approach to the defense and maintenance of Jewish identity is itself resonant with ancient biblical traditions associated with Jewish survival in a hostile environment. Migration from Europe to Palestine, local hostilities with the resident Arab population, and vacillating relationships with British Mandate forces have all exerted an influence on the format and application of Krav-Maga as it evolved through time. The interactions between these historical events not only created a distinctive system of combat, but also played a part in the formation of Jewish national identity, a more robust and self-reliant ideology and, ultimately, a national homeland.

The combat discipline itself, although bearing different names at different points in its history, essentially constitutes a single, evolving system, which has picked up modifications as a consequence of Jewish historical events. In Feldenkrais' days (and before), the training was called self-defense and Jujitsu. During 1933-1941, the predominant title was Sport Magen (though it was also sometimes referred also as Jujitsu). The name Kapap appeared once the discipline evolved to incorporate short-stick fighting. By the mid-1950s, the term Krav-Maga had established its dominance. However, throughout these periods, as argued above, the principles of self-reliance and unconscious reaction, as well as the use of experimentation to develop appropriate responses to changing threats, have been constant features.

Krav-Maga would not be the first combat discipline to be recognized as an example of the ICH of a nation; some Chinese martial arts [50] and Taekkyeon (a traditional Korean martial art) [51] have already been recognized. However Krav-Maga, which grew out of European Jewish history and as a response to dramatic cultural change, embodies the memory of resistance to historical oppression. In this respect, it closely resembles Capoeira (an Afro-Brazilian cultural practice of simultaneous fighting and dancing), which was recognized by UNESCO in 2014 as part of the intangible cultural heritage of Brazil [52]. Krav-Maga meets the UNESCO criteria for intangible cultural heritage in that it is recognized by Israelis as part of their cultural heritage, it is passed down from 
generation to generation, and it has been constantly evolving in response to the vicissitudes of Jewish history for more than a century. Krav-Maga is widely practiced internationally, while being recognized as an authentic form of Israeli hand-to-hand combat. Thus it reinforces Israeli national identity while promoting cooperation among practitioners from many different countries. It follows that there is a solid justification for declaring and protecting Krav-Maga as an element of the intangible cultural heritage of Israel.

\section{Conflicts of Interest}

The author declares no conflicts of interest regarding the publication of this paper.

\section{References}

[1] Mor, G. (2018) History and Singularity of Krav-Maga. The International Journal of the History of Sport.

[2] Lichtenstein, K. (2008) Krav-Maga the Israeli Discipline of Defense. Orion Books, Israel, 13-23.

Almedrala, A. (2014) We Tried It: Krav Maga Worldwide. Huff Post. https://www.huffpost.com/entry/krav-maga_n_4784896

Tylor, J. (2009) How This Man Taught Me to Kill in Four Moves. Independent. http://www.independent.co.uk/news/uk/home-news/how-this-man-taught-me-to-k ill-in-four-moves-1790034.html

[3] Browning, L. (2010) Trading Karate Kicks for Deadly Force. The New York Times. http://www.nytimes.com/2010/08/01/fashion/01krav.html Levitz, D. (2008) Tough Enough? Try Krav-Maga. The Washington Post. http://www.washingtonpost.com/wpdyn/content/article/2008/09/25/AR2008092503 716.html

[4] 2015 Charlie Hebdo Attacks Fast Facts. World CNN. https://edition.cnn.com/2015/01/21/europe/2015-paris-terror-attacks-fast-facts/ind ex.html

[5] Youtube. Learn How to Defend Yourself: IDF Style. https://www.youtube.com/watch?v=LVJ8WjCi8Lg

[6] Mor, G. (2018) History and Singularity of Krav-Maga. The International Journal of the History of Sport.

[7] Kolot, I. (1996) The Zionist Movement and the Arabs, The Center for Technological Education. https://lib.cet.ac.il/pages/item.asp?item=14099\&source=748

[8] Howard, P. (2003) Heritage-Management, Interpretation, Identity. Continuum Publication, London, 6-7.

Smith, L. (2006) Uses of Heritge. Routledge Publication, Britain, 1-7.

[9] Yahaya, A. (2006) The Scope and Definitions of Heritage: From Tangible to Intangible. International Journal of Heritage Studies, 12, 299.

Vecco, M. (2010) A Definition of Cultural Heritage: From the Tangible to the Intangible. Journal of Cultural Heritage, 11, 321.

[10] (2003) Convention for the Safeguarding of the Intangible Cultural Heritage. Paris, MISC/2003/CLT/CH/14, 2.

[11] Frenkel, J. (2003) Blood and Politics: Damascus Blood Libel, the Jews and the World. Zalman Shazar Center of Israel History. 
Shapira, A. (2012) Israel: A History 1881-2000. Zalman Shazar Center Publication, Jerusalem, 16.

[12] Shapira, A. (2012) Israel: A History 1881-2000. Zalman Shazar Center Publication, Jerusalem, 16.

[13] Shapira, A. (2012) Israel: A History 1881-2000. Zalman Shazar Center Publication, Jerusalem, 18.

[14] New World Encyclopedia Contributors. Alexander II of Russia, New World Encyclopedia. http://www.newworldencyclopedia.org/entry/Alexander_II_of_Russia

[15] Shapira, A. (2012) Israel: A History 1881-2000. Zalman Shazar Center Publication, Jerusalem, 22-31.

[16] Pinsker, J.L. (1951) Auto-Emancipation. Zionist Union Publication.

[17] Yosef, O. (2000) Patriarchs Branch Tree, on Pirkei Avot. Maor Israel Publishing, Jerusalem, 45.

[18] Shapira, A. (2012) Israel: A History 1881-2000. Zalman Shazar Center Publication, Jerusalem, 25-28.

[19] Kaufman, H. (1996) The National Ideas of the Term Muscle Judaism. Movement. Journal of Physical Education and Sport Sciences, 3, 261-282.

[20] Ministry of Education (2010) Ze'ev Jabotinsky. Department for Israeli Culture and Heritage, Jerusalem, 2. http://meyda.education.gov.il/files/noar/zbotinski_cv.pdf

[21] Galili, Y. and Koufman, H. (2009) Sport Zionist Ideology and the State of Israel. Social Issues in Israel, 8, 10-31.

[22] Shapira, A. (2012) Israel: A History 1881-2000. Zalman Shazar Center Publication, Jerusalem, 42.

[23] (1984) The Second Wave of Immigration 1903-1914. The Center for Technological Education. https://lib.cet.ac.il/Pages/item.asp?item=12916

[24] Shapira, A. (2012) Israel: A History 1881-2000. Zalman Shazar Center Publication, Jerusalem, 58-59.

[25] Shapira, A. (2012) Israel: A History 1881-2000. Zalman Shazar Center Publication, Jerusalem, 59-60.

[26] Shapira, A. (2012) Israel: A History 1881-2000. Zalman Shazar Center Publication, Jerusalem, 74-78.

[27] Yakova M. and Lavi S. (2004) Journals of the Third Wave of Imigration. Katedra Journal, 113, 144

[28] Bar-Maoz, D. (2012) From Colony to a City, Story of the City of Rehovot, Israel. S.H.R Print, 34.

[29] Cohen-Gil, M. (2013) The Israelis Who Wished to Cure the World. Keter Publication, Jerusalem, 34

[30] Hagana Organization Official Website. http://www.hahagana.org.il/show_item.asp?levelId=59855\&itemId=48480\&itemTyp $\mathrm{e}=3$

[31] Feldenkrais, M. (2013) Thinking and Doing. Genesis II Publishing Inc., 185, 473, 492.

[32] Cohen-Gil, M. (2013) The Israelis Who Wished to Cure the World. Keter Publication, Jerusalem, 35.

[33] Nevo, Y. (1979) The Arabs of Israel and the White Paper of 1939. Katedra Journal, 12, 148-163. 
[34] Yafe, S.D. (1938) Hachoger. Hapoel Center Publishing, Tel-Aviv.

[35] Gross, N. and Nativ, M. (2016) Krav-Maga Development. In: Lidor, R. and Sharvit, N., Eds., Military Fitness Alignment, Seven Decades, I.D.F Publication, 29.

Kofler, G. (1941) Sport Magen Training Manuals. Courtesy of Zvi Nishri Archive at Wingate Institute, AD1.9/0133.

[36] Mamet, G. (1987) The Friend-Orde Charles Wingate. In: The Days of Wall and Tower 1936-1939, Yad Ytzhak Ben Zvi Publishing, 171-180.

[37] Gelber, Y. (1986) A Seed for an Organized Hebrew Army. Itzahak Ben Zvi Publication, 4.

[38] Gross, N. (2010) Kapap-From the Field to the Battlefield. Mevashlim Sfarim Publication, 60 .

[39] Gross, N. (2010) Kapap-From the Field to the Battlefield. Mevashlim Sfarim Publication, 67.

[40] Mor, G. and Moriya, A. (2016) Krav-Maga, Teaching with Doubt. A.R. Print, 15.

[41] Gross, N. and Nativ, M. (2016) Krav-Maga Development. In: Lidor, R. and Sharvit, N., Eds., Military Fitness Alignment, Seven Decades, I.D.F. Publication, 34.

[42] I.D.F. Archives.1949.1034.38 (p. 4, 6, 24, 27, 47, 63, 64, 123)1949.1034.58 (p. 6, 18, $24,27,80-83,149,161,207,227-233) 1954.254 .47$

[43] Ben-Dov, D., et al. (2015) Military Krav-Maga Concepts and Operation. IDF Magazine, Volume B, 130.

[44] Ben-Dov, D., et al. (2015) Military Krav-Maga Concepts and Operation. IDF Magazine, Volume B, 129.

[45] (1971) Wingate Institute Bulletin, Volume 9, 6. Courtesy of Zvi Nishri Archive at Wingate Institute.

[46] Hamber, G. (2012) The War on Krav-Maga. Marachot Journal, 446, 51.

[47] Krav Maga Global. https://krav-maga.com/kmg-locations Krav Maga Alliance. http://www.kravmagaalliance.com/affiliates IKMF Krav Maga. https://kravmaga-ikmf.com/locations

[48] Wingate College. http://krav-maga.wincol.ac.il/?page_id=1878 Facebook. https://www.facebook.com/events/1405577719502450 Israeli College of Sports. https://www.ics.org.il/en/krav-maga-instructor

[49] Bar-On Cohen, E. (2010) Globalization of the War on Violence: Israeli Close Combat Krav-Maga and Sudden Alterations in Intensity. Journal of Social Anthropolo$g y$, 18, 267-288. https://doi.org/10.1111/j.1469-8676.2010.00111.x

[50] Feng, Z. (2008) Research of Traditional Wushu Protection, in the View of Intangible Cultural Heritage. Journal of Sport and Science, 29, 55-57.

Zhang, Z. (2014) Research on Representative Heritage of Traditional Martial Arts from Perspective of Intangible Cultural Heritage. China Sport Science and Technology, 50, 57-61.

[51] Taekkyeon, a Traditional Korean Martial Art (2011) UNESCO Sixth Session of the Intergovernmental Committee 13.44: ICHDOC. Bali, Indonesia.

[52] Capoeira Circle-Intangible Heritage (2014) UNESCO, Ninth Session of the Intergovernmental Committee (9.COM) 892 Paris. 